\title{
Evaluasi Implementasi Kurikulum 2013 pada Mata Pelajaran Matematika Di SMP Negeri
}

\author{
Apriyani Lisnawati Mowendu \\ Universitas Kristen Satya Wacana \\ yanimowendu@gmail.com \\ Slameto \\ President University \\ slameto@president.ac.id \\ Yari Dwikurnaningsih \\ Universitas Kristen Satya Wacana \\ yari.dwikurnaningsih@uksw.edu
}

\begin{abstract}
The purpose of this study is to describes the implementation of curriculum 2013, especially on math subject at SMP Negeri 7 Salatiga. Curriculum 2013 is one of government's strategic to decrease the quality of education. SMP Negeri 7 Salatiga is one of school that has implemendted the curriculum since 2014. This evaluation research departs from the problem that found on implementation of curriculum 2013 at SMP Negeri 7 Salatiga, especially on math. The subjects of this research are the student and math teachers in SMP Negeri 7 Salatiga. Data collection techniques used in this research were interviews, observation, questionnaires and documentation. Data analysis technique used in this research is descriptive qualitative. This study describes how the implementation of curriculum 2013 in schools is based on model of countenance stake evaluation and is guided by the standards that used. The results showed that: 1) at the antecedents stage, 100\% meet the standards of the Kurikulum 2013 tools and lesson planning; 2) at the transaction stage, 40\% have not met the standards for learning implementation and $40 \%$ have not met the standards for the authentic assessment; 3) at the outcomes stage of $83.3 \%$ not meeting the standards for authentic assessment results.
\end{abstract}

Keywords: Program Evaluation, Implementation of Curriculum 2013, Countenance Stake Model

\section{Article Info}

\section{PENDAHULUAN}

Kurikulum 2013 atau K-13 merupakan Kurikulum yang diterapkan pada saat ini. Penerapan Kurikulum 2013 pada awalnya menimbulkan pro dan kontra khususnya dikalangan tenaga pendidik dan kependidikan. Peralihan Kurikulum dinilai memiliki rentang waktu yang cepat sehingga sekolah harus beradaptasi dengan Kurikulum baru dalam rentang waktu yang relatif sedikit. Hal tersebut secara tidak langsung menuntut sekolah untuk membuat persiapan dan strategi baru dalam rangka menerapkan Kurikulum yang baru. Kurikulum 2013 sebenarnya memiliki tujuan 
yang sangat baik yaitu untuk mewujudkan terjadinya peningkatan dan keseimbangan antara kompetensi sikap (attitude), keterampilan (skill) dan pengetahuan (knowledge). Kurikulum 2013 telah dilaksanakan dan diikuti oleh beberapa sekolah. Namun pada kenyataannya masih banyak sekolah yang menemukan hambatan dalam penerapan Kurikulum 2013. Berbagai usaha dilakukan dalam rangka keberhasilan pelaksanaan Kurikulum 2013 diantaranya diklat, seminar, workshop dan pelatihan lainnya yang diikuti oleh guru, kepala sekolah, komite dan para stakeholder lainnya.

SMP Negeri 7 Salatiga adalah salah satu sekolah di kota Salatiga yang telah menerapkan Kurikulum 2013. Sekolah telah melaksanakan Kurikulum 2013 mulai dari tahun 2014 dengan dilengkapi berbagai persiapan. Persiapan yang dilakukan salah satunya adalah dengan mengirim guru-guru untuk mengikuti penataran. Guru-guru diperlengkapi dengan buku pedoman khusus untuk melaksanakan Kurikulum 2013. Guru-guru juga diberikan pelatihan mengenai pendekatan $5 \mathrm{M}$ yaitu, Mengamati, Menanya, Mengumpulkan data, Mengasosiasi dan Menyimpulkan. Berbagai usaha dan persiapan yang dilakukan sekolah dalam melaksanakan Kurikulum 2013 ternyata tidak menjamin bahwa sekolah tidak menemui kendala. Berdasarkan studi pendahuluan pada bulan November 2017, sekolah menjelaskan berbagai kendala yang dihadapi dalam pelaksanaan Kurikulum 2013. Hal yang dirasa cukup menyulitkan yaitu pada proses penilaian, sehingga diakui oleh sekolah memang masih berjalan kurang maksimal.

Dalam pelaksanaan pendidikan sesuai dengan Kurikulum 2013 penyelenggara harus memperhatikan setiap aspeknya, mulai dari perencanaan pembelajaran, proses pembelajaran sampai kepada proses penilaian. Ada empat standar penting yang perlu diperhatikan dalam proses pembelajaran oleh penyelenggara pendidikan khususnya sekolah, yakni; (1) standar kompetensi lulusan; (2) standar isi; (3) standar proses; (4) standar penilaian. Adanya standar pendidikan dan perubahan Kurikulum bertujuan untuk memajukan pendidikan Indonesia dalam berbagai bidangnya, tidak terkecuali dalam pendidikan matematika. Guru mata pelajaran matematika dituntut untuk melaksanakan pembelajaran sesuai dengan standar pendidikan dan Kurikulum 2013. Mata pelajaran matematika merupakan salah satu mata pelajaran penting untuk diajarkan di sekolah, terlebih lagi merupakan salah satu mata pelajaran yang diujikan secara nasional. Matematika pada hakikatnya berhubungan erat dengan aktivitas keseharian manusia seperti halnya seni, bahasa, musik, atau membuat karya yang bagus, yang secara intrinsik berharga.

Berdasarkan studi pendahuluan, sekolah juga menjelaskan bahwa secara kemampuan akademis khususnya pada mata pelajaran matematika, SMP Negeri 7 Salatiga masih berada dibawah SMP piloting Kurikulum 2013 lainnya. Kendala-kendala yang dihadapi dalam pelaksanaan Kurikulum 2013 di SMP Negeri 7 Salatiga mengindikasikan bahwa ada kesenjangan dalam pelaksanaannya, dan masih terdapat kemungkinan ada kendala atau kesenjangan lainnya.

Dalam suatu implementasi program pendidikan seperti implementasi Kurikulum, evaluasi merupakan hal yang sangat penting untuk dilaksanakan. Evaluasi pelaksanaan Kurikulum 2013 memiliki berbagai manfaat dan dapat membantu sekolah dalam kelanjutan pelaksanaannya. Pendidikan matematika juga akan berhasil dengan baik jika pendidikan matematika bermutu dan bermakna bagi peserta didik. Salah satu upaya untuk meningkatkan kualitas pendidikan matematika serta membuat pendidikan matematika bermakna ialah melalui kegiatan penelitian. Hasil-hasil penelitian pendidikan matematika akan memperkaya konten, strategi, metode, teknik evaluasi yang 
baik bagi pembelajaran matematika. Implementasi hasil-hasil penelitian di kelas akan mampu meningkatkan kualitas pembelajaran matematika, yang pada gilirannya dapat meningkatkan kualitas pendidikan matematika. Oleh karena itu, untuk mengetahui implementasi Kurikulum 2013 pada pembelajaran matematika di SMP Negeri 7 Salatiga, maka perlu dilaksanakan penelitian evaluasi implementasi Kurikulum 2013. Penelitian ini menggunakan Evaluasi countenance stake untuk mengevaluasi implementasi Kurikulum 2013. Evaluasi model countenance dipilih karena model ini dapat mengevaluasi secara menyeluruh semua aspek yang dievaluasi dan dapat memberikan pertimbangan-pertimbangan berdasarkan deskripsi hasil analisis data yang diperoleh. Menurut Yusuf (2000), evaluasi countenance stake mengklasifikasikan adanya tiga tahap dalam evaluasi yakni, Anteceden (konteks awal), Transaksi (proses), dan Hasil (outcomes). Berdasarkan latar belakang diatas terdapat empat permasalahan yang akan dipecahkan yaitu: (1) bagaimanakah implementasi Kurikulum 2013 mata pelajaran matematika di SMP Negeri 7 Salatiga pada tahap pendahuluan (antecedents); bagaimanakah implementasi Kurikulum 2013 mata pelajaran matematika di SMP Negeri 7 Salatiga pada tahap proses (transaction); (3) bagaimanakah implementasi Kurikulum 2013 mata pelajaran matematika di SMP Negeri 7 Salatiga pada tahap hasil (outcomes); (4) apa sajakah yang dapat menjadi pertimbangan dalam rangka keberlanjutan implementasi Kurikulum 2013 pada mata pelajaran matematika di SMP Negeri 7 Salatiga. Melalui penelitian diharapkan dapat memberikan manfaat baik secara teoritis maupun praktis bagi keberlangsungan program pendidikan di Indonesia, khususnya dapat memberikan manfaat bagi SMP Negeri 7 Salatiga sebagai sekolah sasaran penelitian.
Terdapat sejumlah penelitian terkait dengan evaluasi implementasi Kurikulum 2013. Penelitian yang dilakukan oleh Wasino tentang evaluasi Kurikulum 2013 di Kalangan Guru SMP di Cluster 2 Kabupaten Boyolali Tahun 2015 menunjukkan hasil sebagai berikut; (1) pelaksanaan Kurikulum 2013 dalam hal penyusunan Rencana Pelaksanaan Pembelajaran sudah berjalan dengan baik meskipun belum maksimal, dengan catatan semua komponen masih ada kesenjangan terutama pada komponen pemilihan sumber belajar, media dan penilaian; (2) pelaksanaan Kurikulum 2013 dalam hal pelaksanaan pembelajaran berjalan dengan baik meskipun belum maksimal, dengan catatan pelaksanaan komponen penilaian, pemanfaatan media dan penguasaan materi masih harus mendapat perhatian lebih; (3) hambatan dalam penyusunan RPP dan pelaksanaan pembelajaran Kurikulum 2013 terletak pada kekurangpahaman guru terhadap regulasi yang harus diikuti terutama pelaksanaan penilaian yang komplek dan belum terdukung penguasaan teknologi informasi yang memadai, selain itu padatnya jam mengajar sehingga kurang maksimal dalam penyusunan perencanaan mengajar. Penelitian lainnya yang terkait dengan evaluasi Kurikulum 2013 dan menggunakan evaluasi model countenance stake yaitu penelitian yang dilakukan oleh Nurmin \& Kartowagiran (2013). Hasil evaluasi menunjukan: (1) Sebagian besar $(91,2 \%)$ guru SD di Kecamatan Salahutu, Kabupaten Maluku Tengah menyatakan perencanaan pembelajaran tematik dengan kategori cukup baik; (2) Sebagian besar (76,5\%) guru SD di Kecamatan Salahutu, Kabupaten Maluku Tengah melaksanakan proses pembelajaran tematik dengan kategori cukup baik; (3) Sebagian besar (91,2\%) guru SD di Kecamatan Salahutu, Kabupaten Maluku Tengah mampu melaksanakan penilaian pembelajaran tematik dengan kategori cukup baik. Penelitian lainnya dilakukan oleh oleh Noviatmi (2015) di 
Kabupaten Magelang menggunakan Model Evaluasi Countenance dari Stake. Pertimbangan/rekomendasi dalam penelitian ini digunakan sebagai bahan rujukan terhadap perbaikan implementasi Kurikulum 2013 kelas I \& IV SD di Kabupaten Magelang tahun pelajaran 2014/2015.

Undang-Undang Republik Indonesia nomor 20 tahun 2003 tentang sistem Pendidikan Nasional menyatakan: "Kurikulum adalah seperangkat rencana dan pengaturan mengenai tujuan, isi, dan bahan pelajaran serta cara yang digunakan sebagai pedoman penyelenggaraan kegiatan pembelajaran untuk mencapai tujuan pendidikan tertentu". Sesuai dengan perkembangan jaman di setiap periode, kurikulum selalu mengalami perubahan dalam rangka penyempurnaan dan penyesuaian. Oleh karena itu kurikulum di Indonesia beberapa kali mengalami perubahan dan pergantian. Jika dibandingkan dengan Kurikulum sebelumnya yakni kurikulum tingkat satuan pendidikan (KTSP) maka Kurikulum 2013 mengalami perubahan di beberapa elemen yaitu: (1) elemen kompetensi lulusan mencakup kompetensi sikap, pengetahuan, dan keterampilan secara berimbang; (2) elemen materi/ isi yaitu adanya keseimbangan antara materi untuk mendukung kemampuan sikap, keterampilan, dan pengetahuan dan semua konten mendukung ketiga kompetisi diatas secara berimbang; (3) pendekatan untuk IPS dan IPA adalah pembelajaran terpadu; (4) proses pembelajaran yang semula terfokus pada eksplorasi, elaborasi, dan konfirmasi dilengkapi dengan mengamati, menanya, mengolah, menalar, menyajikan, dan mencipta yang dikenal dengan pendekatan saintifik; belajar tidak hanya terjadi diruang kelas, tetapi juga di lingkungan sekolah dan masyarakat, guru bukan satu-satunya sumber belajar, sikap tidak hanya diajarkan secara verbal, tetapi melalui contoh dan teladan; (5) penilaian hasil belajar penilaian berbasis kompetensi, pergeseran dari penilaian melalui tes (mengukur kompetensi pengetahuan berdasarkan hasil saja) menuju penilaian otentik (mengukur kompetensi sikap, keterampilan, dan pengetahuan berdasarkan proses dan hasil), penilaian tidak hanya level $\mathrm{KD}$, tetapi juga kompetensi inti dan SKL, mendorong pemanfaatan portofolio yang dibuat siswa sebagai instrumen utama penilaian dan penilaian mandiri oleh siswa.

Scientific Mathematic merupakan proyek Eropa yang melibatkkan kerjasama interdisiplinary antara matematika dan ilmu pengetahuan. Hal ini bertujuan untuk mengembangkan pembelajaran ke arah belajar yang komprehensif dan multidimensional mengenai isi dan konsep matematika. Menurut Beckmann (2009) ide dasarnya adalah untuk mendorong pembelajaran matematika dalam konteks ilmiah dan kegiatan siswa. Pendekatan ini mengaitkan antara matematika dengan ilmu pengetahuan, sehingga siswa akan mempelajari matematika dengan cara yang menarik. Belajar dengan berkegiatan akan berkontribusi terhadap pemahaman intuitif matematika siswa. Dengan kata lain, belajar matematika yang baik adalah mengalami atau berkegiatan. Lebih lanjut menurut Beckmann, tahap-tahap pendekatan saintifik pada pembelajaran matematika yaitu (1) pengumpulan data dari percobaan; (2) pengembangan dan penyelidikan suatu model matematika dalam bentuk representasi yang berbeda; (3) refleks. Tahap-tahap tersebut kemudian diterapkan pada Kurikulum 2013 di Indonesia dan dijabarkan menjadi lima, yaitu mengamati, menanya, menalar, mencoba, dan mengkomunikasikan (Kemendikbud, 2016.a). Kemudian kelima tahapan ini diterapkan pada proses pembelajaran semua mata pelajaran termasuk didalamnya pada proses pembelajaran matematika dasar dan menengah. Dalam pembelajaran matematika Kurikulum 2013 peserta didik diharapkan aktif sehingga proses pembelajaran menjadi lebih bermakna.

Evaluasi countenance merupakan jenis evaluasi program yang dianggap cukup 
memadai dalam menilai pembelajaran secara kompleks. Model ini dikembangkan oleh Stake. Kata countenance berasal dari kata dalam bahasa Inggris yang berarti menyetujui atau persetujuan. Secara istilah, evaluasi countenance berarti evaluasi yang menekankan pelaksanaan deskripsi dan pertimbangan. Kaitan arti dengan asal katanya adalah pada pertimbangan yang diperoleh dari evaluator sehingga menimbulkan keputusan atau persetujuan tentang suatu hal. Menurut Yusuf dalam Widoyoko (2009), evaluasi ini menekankan pada adanya pelaksanaan dua hal pokok: deskripsi dan pertimbangan, serta membedakan adanya tiga tahap dalam evaluasi, yaitu; Anteceden (konteks awal), Transaksi (proses), dan Hasil (outcomes). Model evaluasi countenance yang diajukan Stake memiliki dua komponen penting, yaitu deskripsi dan pertimbangan yang masing-masing terdiri dari dua kategori. Langkah-langkah yang harus ditempuh dalam melaksanakan evaluasi countenance tercakup dalam empat langkah pasti. Pertama, evaluator dapat melakukan studi dokumen atau wawancara kepada pengembang program, baik berhubungan dengan persyaratan awal, proses, serta hasil. Kedua, sehubungan dengan kategori observasi, evaluator harus mengadakan analisis kongruen, yaitu menganalisa implementasi dari rencana. Apakah sesuai atau terjadi penyimpangan. Jika terjadi penyimpangan, faktor-faktor apa saja yang menyebabkannya. Ketiga, tugas evaluator berikutnya adalah memberikan pertimbangan mengenai program yang sedang dikaji, oleh karenanya perlu standar yang dapat diperoleh dari sekolah. Keempat, memberi pertimbangan terhadap hasil analisis ketiga langkah sebelumnya. Pertimbangan dapat diperoleh dengan mengumpulkan data dari sekelompok orang yang memiliki kualifikasi untuk memberikan pertimbangan.

Berdasarkan uraian tersebut dapat dipahami bahwa model evaluasi countenance dapan menilai secara komprehensif, yang dimulai dari pengumpulan data, analisis data, memberikan pertimbangan terhadap program, memberi pertimbangan terhadap hasil.

\section{METODE PENELITIAN}

Penelitian ini merupakan penelitian evaluasi dengan menggunakan pendekatan deskriptif kualitatif. Model evaluasi yang digunakan yaitu model evaluasi countenance stake yang menekankan pada deskripsi dan pertimbangan. Terdapat tiga tahapan dalam model evaluasi countenance stake yaitu : (1) tahap pendahuluan (antecedents); (2) tahap proses (transaction); (3) tahap hasil (outcomes). Teknik pengumpulan data yang dilakukan dalam penelitian ini berupa wawancara, observasi, angket dan dokumentasi yang digunakan pada tahap anteceden (konteks awal). Penelitian ini menggunakan triangulasi teknik dan triangulasi sumber untuk menguji validitas data. Analisis data yang digunakan dalam penelitian ini adalah teknik analisis deskriptif kualitatif. Data yang didapatkan melalui teknik pengumpulan data selanjutnya dikategorikan dan dianalisis dengan berpedoman pada kriteria dari Kemendikbud (2016.a). Khusus untuk data yang didapatkan dengan menggunakan angket, peneliti memilih kategorisasi berdasarkan kriteria pengolahan angket oleh Mardapi (2008). Setelah melakukan pengolahan data dan didapatkan hasil dari olah data tersebut, data dianalisis dengan melihat kategori-kategori yang tersedia. Hasil analisis kemudian dibandingkan dengan standar yang dipakai, untuk melihat apabila terdapat ketimpangan dalam setiap aspek yang diteliti. Kemudian berdasarkan ketimpanganketimpangan yang ditemui, peneliti harus menggali informasi lebih lanjut lewat wawancara mendalam atau observasi lanjutan untuk mengetahui hal-hal yang menjadi hambatan. Selanjutnya berdasarkan ketimpangan dan hambatan yang menyebabkannya, pertimbangan atau rekomendasi dalam rangka keberlanjutan 
implementasi Kurikulum 2013 pada mata pelajaran matematika di SMP Negeri 7 Salatiga dapat ditentukan. Pertimbangan ditentukan dengan berpedoman pada standar yang dipakai, teori-teori pendukung, masukan dari stakeholder dan pendapat peneliti sendiri.

\section{HASIL PENELITIAN DAN PEMBAHASAN}

\section{Hasil Penelitian}

Penelitian evaluasi Kurikulum 2013 dengan menggunakan model countenance stake ini mengandung dua hal utama yakni deskripsi dan pertimbangan. Deskripsi dan pertimbangan diperoleh dengan melewati tiga tahap dalam penelitian yaitu tahap pendahuluan (antecedent), tahap proses (transaction) dan tahap hasil (outcomes).

1. Tahap Pendahuluan (Antecedent)

Tahap antecedent dalam penelitian ini adalah kelengkapan perangkat Kurikulum 2013 sebagai sarana dan prasarana pelaksanaan Kurikulum 2013, serta perencanaan pembelajaran. Hasil penelitian melalui studi dokumen terkait kelengkapan Kurikulum 2013 di SMP Negeri 7 Salatiga disajikan dalam bentuk tabel pada tabel 1 sebagai berikut.

Tabel 1. Hasil Penelitian Kelengkapan Perangkat Kurikulum 2013

\begin{tabular}{llll}
\hline No & Rentang Skor & Kategori & Persentase \\
\hline 1. & $91-100$ & Sangat Baik & $100 \%$ \\
\hline 2. & $76-90$ & Baik & $0 \%$ \\
\hline 3. & $61-75$ & Kurang & $0 \%$ \\
\hline 4. & $\leq 60$ & Sangat Kurang & $0 \%$ \\
\hline Sumber: Data penelitian &
\end{tabular}

Berdasarkan tabel tersebut diatas dapat dilihat bahwa terdapat $100 \%$ untuk kategori sangat baik, $0 \%$ dalam kategori baik, kurang dan sangat kurang. Keadaan perangkat Kurikulum 2013 khususnya mata pelajaran Matematika di SMP Negeri 7 Salatiga secara keseluruhan sangat baik dan lengkap. Sesuai dengan hasil studi dokumen, setiap kelas dan guru mata pelajaran matematika memiliki perangkat yang lengkap untuk pelaksanaan implementasi Kurikulum 2013, khususnya dalam pembelajaran matematika. Selain berdasarkan hasil tersebut, peneliti kemudian meminta konfirmasi dari guru bagian Kurikulum tentang kelengkapan perangkat Kurikulum. Menurut guru bagian Kurikulum kelengkapan K-13 sangat penting, sesuai dengan pernyataannya dalam wawancara guru menjelaskan bahwa "penting bagi kami untuk memperhatikan kelengkapan Kurikulum 2013 karena sangat berhubungan dengan proses pembelajaran" (Wawancara 5 Maret 2018)

Aspek lainnya yang ditekankan pada tahap pendahuluan atau antecedent dalam penelitian ini adalah perencanaan pembelajaran. Perencanaan pembelajaran disusun guru dalam bentuk RPP, oleh karena itu studi dokumentasi terkait perencanaan pembelajaran dilakukan terhadap RPP yang dibuat oleh seluruh guru mata pelajaran matematika. Hasil penelitian melalui studi dokumentasi perencanaan pembelajaran Kurikulum 2013 pada mata pelajaran matematika di SMP Negeri 7 Salatiga disajikan dalam tabel 2 berikut.

Tabel 2. Hasil Penelitian Perencanaan Pembelajaran

\begin{tabular}{cccc}
\hline No & Rentang Skor & Kategori & Persentase \\
\hline 1. & $91-100$ & Sangat Baik & $0 \%$ \\
\hline 2. & $76-90$ & Baik & $100 \%$ \\
\hline 3. & $61-75$ & Kurang & $0 \%$ \\
\hline 4. & $\leq 60$ & Sangat Kurang & $0 \%$ \\
\hline Sumber: Data penelitian & &
\end{tabular}

Sumber: Data penelitian 
Hasil pengamatan terhadap perencanaan pembelajaran matematika Kurikulum 2013 yang dibuat oleh guru mata pelajaran matematika di SMP Negeri 7 Salatiga untuk kategori sangat baik terdapat $0 \%, 100 \%$ berkategori baik, $0 \%$ termasuk dalam kategori kurang, dan $0 \%$ dapat dikategorikan sangat kurang. Perencanaan pembelajaran yang dituangkan dalam RPP merupakan aspek yang sangat penting dalam implementasi Kurikulum 2013. Pada aspek perencanaan pembelajaran dapat dilihat bahwa terdapat $100 \%$ berkategori baik dari hasil observasi RPP yang apabila dibandingkan dengan standar dapat dikatakan sudah memenuhi. Dapat dikatakan seluruh RPP guru matematika yang diteliti melalui studi dokumentasi adalah berkategori baik. Hal ini berarti pada aspek perencanaan pembelajaran tidak memerlukan judegement atau pertimbangan.
Terkait dengan hasil penelitian melalui studi dokumen peneliti kemudian melakukan konfirmasi melalui guru matematika tentang RPP yang telah disusun. Menurut guru matematika, guru-guru matematika SMP Negeri 7 Salatiga telah menyusun RPP sesuai pedoman penyusunan RPP dan telah memasukan penerapan pendekatan saintifik didalamnya. (JM, Wawancara 5 Maret 2018)

2. Tahap Proses (Transaction)

Ada dua aspek yang ditekankan dalam tahap proses atau transaction dalam penelitian ini, yakni pelaksanaan pembelajaran dan pelaksanaan penilaian autentik guru mata pelajaran matematika SMP Negeri 7 Salatiga. Berdasarkan hasil observasi yang dilakukan oleh peneliti dan guru senior mata pelajaran matematika diperoleh hasil sesuai dengan yang disajikan pada tabel 3.

Tabel 3. Hasil Observasi Pelaksanaan Pembelajaran Matematika SMP Negeri 7 Salatiga

\begin{tabular}{cllc}
\hline No & Rentang Skor & \multicolumn{1}{c}{ Kategori } & Persentase \\
\hline 1. & $91-100$ & Sangat Baik & $0 \%$ \\
\hline 2. & $76-90$ & Baik & $60 \%$ \\
\hline 3. & $61-75$ & Kurang & $40 \%$ \\
\hline 4. & $\leq 60$ & Sangat Kurang & $0 \%$ \\
\hline
\end{tabular}

Sumber: Data penelitian

Hasil dari observasi pelaksanaan pembelajaran matematika sesuai dengan tabel 3 menunjukkan bahwa terdapat $0 \%$ termasuk dalam kategori sangat baik, $60 \%$ baik, $40 \%$ kurang dan $0 \%$ sangat kurang. Guru mata pelajaran matematika SMP Negeri 7 Salatiga adalah sebanyak 5 orang guru. Oleh karena itu terdapat sebanyak 3 guru $(60 \%)$ termasuk dalam kategori baik dan 2 guru (40\%) termasuk dalam kategori kurang pada pelaksanaan pembelajaran matematika.

Terdapat tiga bagian penting dalam pelaksanaan pembelajaran. Bagian pertama yaitu kegiatan pendahuluan yang berisi apersepsi dan motivasi serta penyampaian kompetensi dan rencana kegiatan oleh guru. Kemudian ada kegiatan inti dimana guru matematika harus menerapkan pendekatan saintifik dalam kegiatan pembelajaran sesuai yang diamanatkan pada Kurikulum 2013. Guru matematika juga harus menerapkan pembelajaran tematik terpadu dan memanfaatkan media pembelajaran. Bagian selanjutnya yaitu penutup pembelajaran yang mengharuskan guru matematika untuk memfasilitasi peserta didik untuk menemukan manfaat dari pembelajaran yang baru saja didapatkan, serta menjadi kesempatan guru untuk menginformasikan rencana kegiatan pembelajaran berikutnya.

Terkait dengan hasil observasi beserta temuan penelitian pada pelaksanaan pembelajaran, peneliti kemudian melakukan konfirmasi kepada guru matematika melalui 
wawancara mendalam. Terdapat beberapa aspek dari hasil observasi yang belum sesuai dengan tahapan kegiatan pembelajaran dan RPP. Terkait hal tersebut melalui wawancara guru memberikan penjelasan

"Dalam Kurikulum 2013 dan RPP yang sudah disusun tentunya ada penerapan pendekatan saintifik, tetapi terkadang saya kalau sudah fokus untuk penanaman konsep akhirnya jadi kurang fokus pada langkahlangkah pendekatan saintifik. Agak sulit untuk selalu sesuai dengan tahapantahapannya" (SM, Wawancara 5 Maret 2018)

Hal yang juga penting dalam pelaksanaan pembelajaran adalah penggunaan media pembelajaran. Hasil observasi menemukan bahwa guru matematika sebagian besar masih belum maksimal dalam pemanfaatan media pembelajaran. Terkait hal tersebut guru menjelaskan

"Kalau sering menggunakan media pembelajaran yang bervariasi memang baik, tetapi kami harus menyediakan waktu yang ekstra untuk menyiapkan, kendalanya juga diwaktu. Masih banyak yang harus dikerjakan khususnya masalah penilaian" (SM, Wawancara 5 Maret 2018).

Aspek kedua dari tahap transaction dalam penelitian ini adalah pelaksanaan penilaian autentik. Pengumpulan data pada aspek ini menggunakan angket yang kemudian diolah dan disajikan sesuai dengan kriteria yang dipakai dalam penelitian ini. Berikut adalah data hasil penelitian yang didapatkan berkenaan dengan pelaksanaan penilaian autentik guru mata pelajaran matematika SMP Negeri 7 Salatiga.

Tabel 4. Hasil Penelitian Pelaksanaan Penilaian Autentik Guru Matematika

\begin{tabular}{cllc}
\hline No & \multicolumn{1}{c}{ Rentang Skor } & \multicolumn{1}{c}{ Kategori } & Persentase \\
\hline 1. & $\geq 57,9$ & Sangat Baik & $20 \%$ \\
\hline 2. & $55,8-57,8$ & Baik & $40 \%$ \\
\hline 3. & $53,6-55,7$ & Kurang & $20 \%$ \\
\hline 4. & $\leq 53,5$ & Sangat Kurang & $20 \%$ \\
\hline
\end{tabular}

Sumber: Data penelitian

Melalui hasil penelitian berkenaan dengan pelaksanaan penilaian autentik oleh guru matematika diketahui bahwa 20\% termasuk dalam kategori sangat baik, $40 \%$ baik, $20 \%$ kurang dan ditemukan 20\% sangat kurang. Guru mata pelajaran matematika di SMP Negeri 7 Salatiga berjumlah 5 guru. Sesuai dengan hasil penelitian sebanyak $20 \%$ atau 1 orang guru yang termasuk dalam kategori sangat baik dalam pelaksanaan penilaian autentik. Kemudian terdapat $40 \%$ atau 2 dari 5 guru yang termasuk dalam kategori baik, sedangkan untuk kategori kurang dan sangat kurang masing-masing terdapat $20 \%$ atau 1 dari 5 guru untuk masing-masing kategori.

Terkait dengan angket yang telah diisi oleh guru dan kemudian diolah oleh peneliti, masih terdapat ketimpangan dari standar pelaksanaan penilaian autentik. Melalui analisis angket ditemukan bahwa guru masih kesulitan dalam pelaksanaan penilaian autentik. Mengenai kesulitan yang dialami oleh guru matematika, melalui wawancara mendalam guru memberikan pernyataan sebagai berikut

"Sebagian besar kami (guru) masih merasa kesulitan dengan pelaksanaan penilaian autentik, tidak hanya bagi guru matematika saja, guru mata pelajaran lain sebagian juga seperti itu (kesulitan). Masalahnya adalah penilaian autentik ada 3 aspek, belum lagi bentuk penilaiannya juga bervariasi, ada penilaian dengan penilaian kinerja, portofolio dan proyek. Memang belum maksimal apalagi diawal implementasi Kurikulum, tetapi kami selalu berusaha tetap fokus dan melakukan yang terbaik khususnya dalam menilai tiga aspek tadi (pengetahuan, keterampilan dan sikap)" (Wawancara JM, 5 Maret 2018).

3. Tahap Hasil (Outcomes)

Ada tiga aspek dalam penilaian autentik yaitu aspek sikap, pengetahuan dan keterampilan. Pengumpulan dan analisis data 
untuk hasil penilaian autentik dilakukan dengan studi dokumentasi hasil penilaian autentik siswa. Data yang didapatkan dari ketiga aspek tersebut diolah dan kemudian disajikan sesuai dengan kategori yang dipakai dalam penelitian. Hasil penilaian autentik dapat dilihat dalam tabel 5 berikut.

Tabel 5. Hasil Penilaian Autentik

\begin{tabular}{cccc}
\hline No & Rentang Skor & Kategori & Persentase \\
\hline 1. & $91-100$ & Sangat Baik & $0 \%$ \\
\hline 2. & $76-90$ & Baik & $16,7 \%$ \\
\hline 3. & $61-75$ & Kurang & $25 \%$ \\
\hline 4. & $\leq 60$ & Sangat Kurang & $58,3 \%$ \\
\hline
\end{tabular}

Sumber: Data penelitian

Hasil olah data berkenaan dengan hasil penilaian autentik mata pelajaran matematika ditemukan bahwa $0 \%$ termasuk dalam kategori sangat baik, $16,7 \%$ baik, 25\% kurang dan ditemukan 58,3\% sangat kurang. Data tahap hasil (outcomes) diperoleh dari hasil penilaian autentik mata pelajaran matematika dari keseluruhan 24 kelas di SMP Negeri 7 Salatiga. Berdasarkan analisis data terdapat $16,7 \%$ atau 4 dari 24 kelas yang masuk dalam kategori baik. Kemudian terdapat $25 \%$ termasuk dalam kategori kurang atau 6 kelas dari 24 kelas, dan $58,3 \%$ atau sebanyak 14 kelas dari 24 kelas termasuk dalam kategori sangat kurang.

Terkait dengan hasil penilaian autentik peneliti melakukan wawancara mendalam dan observasi untuk mengetahui lebih lanjut mengenai ketimpangan yang terjadi dan faktorfaktor yang menyebabkannya. Sebelum peneliti melaksanakan penelitian dengan tahapan evaluasi model countenance stake, peneliti terlebih dahulu melakukan wawancara untuk mengetahui kondisi sekolah pada awal penelitian. Berdasarkan wawancara dengan guru bagian humas SMP Negeri 7 yang juga merupakan salah satu guru mata pelajaran matematika, dijelaskan mengenai kondisi hasil belajar siswa seperti berikut

"Sebagian besar siswa kami dari segi aspek pengetahuan khususnya matematika memang dapat dikatakan masih rendah apabila dibandingkan dengan sekolah lain yang juga melaksanakan Kurikulum 2013. Siswa masih kesulitan untuk mengikuti penerapan 5M.
Hasil belajar siswa memang masih rendah, khususnya untuk matematika" (JM, Wawancara 15 November 2017)

Kemudian setelah tahapan penelitian dilaksanakan dan memberikan hasil seperti yang sudah dipaparkan, peneliti kembali menggali dari guru tentang hasil penilaian autentik siswa yang terbilang masih rendah. Melalui wawancara guru menjelaskan bahwa

"Saya melihat sebagian besar siswa kurang termotivasi untuk belajar matematika. Belum lagi seperti yang pernah saya jelaskan, bahwa siswa masih kesulitan dalam mengikuti penerapan 5M. Kadang kami sampai kewalahan karena harus menjelaskan berulang-ulang dan tidak semua siswa dapat dijangkau kalau harus menjelaskan ke hampir setiap anak. Kami masih terus mencoba untuk memotivasi siswa untuk semangat dalam belajar matematika, tetapi memang masih sulit" (JM, Wawancara 5 Maret 2018).

Selain menggali informasi lewat wawancara mendalam, peneliti juga mengamati siswa pada saat observasi ke beberapa kelas. Beberapa hal yang menjadi perhatian peneliti yaitu fakta bahwa sebagian siswa kurang aktif dalam pembelajaran matematika dan ada juga yang tampak tidak begitu tertarik dengan pembelajaran. Kemudian terdapat juga siswa dengan kebutuhan khusus sehingga sulit untuk mengikuti pembelajaran.

Keseluruhan hasil penelitian disajikan kedalam tabel matrix countenance stake dengan tujuan mempermudah untuk melihat apabila terdapat kesenjangan dan bagian-bagian yang 
membutuhkan judgement atau pertimbangan. Oleh karena itu disajikan tabel hasil evaluasi implementasi Kurikulum 2013 pada mata pelajaran matematika di SMP Negeri 7 Salatiga secara keseluruhan pada tabel 7 sebagai berikut.

Tabel 7. Hasil Evaluasi Implementasi Kurikulum 2013 pada Mata Pelajaran Matematika di SMPN 7

\begin{tabular}{|c|c|c|c|c|c|}
\hline \multirow[t]{2}{*}{ Tahapan } & \multirow[t]{2}{*}{ Aspek } & \multicolumn{2}{|c|}{ Description Matrix } & \multicolumn{2}{|c|}{ Judgement Matrix } \\
\hline & & Intents & Observations & Standards & Judgements \\
\hline \multirow[t]{2}{*}{$\begin{array}{l}\text { Pendahuluan } \\
\text { (Antecedent) }\end{array}$} & $\begin{array}{l}\text { Kelengkapan } \\
\text { perangkat } \\
\text { Kurikulum } \\
\text { (Sarana } \\
\text { Prasarana) }\end{array}$ & $\begin{array}{l}\text { Ketersediaan } \\
\text { perangkat } \\
\text { kurikulum } \\
\text { untuk setiap } \\
\text { kelas }\end{array}$ & $100 \%$ & $100 \%$ & $\begin{array}{c}\text { Tidak ada } \\
\text { pertimbangan }\end{array}$ \\
\hline & $\begin{array}{l}\text { Perencanaan } \\
\text { Pembelajaran }\end{array}$ & $\begin{array}{l}\text { Perencanaan } \\
\text { Pembelajaran }\end{array}$ & $100 \%$ & $100 \%$ & $\begin{array}{l}\text { Tidak Ada } \\
\text { Pertimbangan }\end{array}$ \\
\hline \multirow{2}{*}{$\begin{array}{c}\text { Proses } \\
\text { (Transaction) }\end{array}$} & $\begin{array}{l}\text { Pelaksanaan } \\
\text { Pembelajaran }\end{array}$ & $\begin{array}{l}\text { Pelaksanaan } \\
\text { pembelajaran }\end{array}$ & $60 \%$ & $100 \%$ & $\begin{array}{c}\text { Ada } \\
\text { Pertimbangan }\end{array}$ \\
\hline & $\begin{array}{l}\text { Pelaksanaan } \\
\text { Penilaian } \\
\text { Autentik }\end{array}$ & $\begin{array}{l}\text { Pelaksanaan } \\
\text { Penilaian } \\
\text { Autentik }\end{array}$ & $60 \%$ & $100 \%$ & $\begin{array}{c}\text { Ada } \\
\text { Pertimbangan }\end{array}$ \\
\hline $\begin{array}{c}\text { Hasil } \\
\text { (Outcomes) }\end{array}$ & $\begin{array}{l}\text { Hasil } \\
\text { Penilaian } \\
\text { Autentik }\end{array}$ & $\begin{array}{l}\text { Ketercapaian } \\
\text { Hasil } \\
\text { Penilaian } \\
\text { Autentik }\end{array}$ & $16,7 \%$ & $100 \%$ & $\begin{array}{c}\text { Ada } \\
\text { Pertimbangan }\end{array}$ \\
\hline
\end{tabular}

Sumber: Data penelitian

Sebagaimana yang terlihat pada matriks hasil penelitian menunjukan bahwa pada tahap pendahuluan (antecedent), yaitu aspek kelengkapan Kurikulum dan perencanaan pembelajaran memiliki persentase $100 \%$ yang artinya tidak perlu adanya pertimbangan atau rekomendasi untuk kedua aspek tersebut. Sesuai dengan matriks dapat dilihat bahwa hasil evaluasi menunjukkan bahwa untuk aspek pelaksanaan pembelajaran matematika Kurikulum 2013 di SMP Negeri 7 Salatiga masih memerlukan rekomendasi. Berdasarkan hasil observasi terdapat $60 \%$ sudah terlaksana dengan baik dan sisanya 40\% masih memerlukan rekomendasi. Persentase 40\% merupakan persentase yang cukup besar, karena itu perlu melihat lebih dalam lagi apa saja yang menjadi hambatan pada aspek pelaksanaan pembelajaran. Selanjutnya diketahui melalui matrix evaluasi model countenance stake, untuk pelaksanaan penilaian autentik masih terdapat $40 \%$ kesenjangan dari standar yang ada. Hal ini menunjukkan untuk pelaksanaan penilaian autentik masih diperlukan pertimbangan.
Selanjutnya berdasarkan matriks, hasil penilaian pada tahap outcomes ini adalah sebesar 16,7\%. Hal tersebut menunjukkan bahwa aspek ini masih sangat memerlukan rekomendasi karena kategori kurang dan sangat kurang lebih besar dibandingkan dengan kategori baik dan sangat baik, yaitu sebesar 83,3\%. Sesuai dengan Kurikulum 2013 terdapat tiga aspek yang dinilai, yakni pengetahuan, sikap dan keterampilan. Hasil penilaian autentik diperoleh dengan menghitung skor keseluruhan dari ketiga aspek pada masingmasing kelas di SMP Negeri 7 Salatiga, kemudian skor diklasifikasikan sesuai dengan rentang skor analisis deskriptif dari kementrian pendidikan dan kebudayaan yang telah dipaparkan pada Bab III (Kemdikbud 2013b).

\section{Pembahasan}

Hasil penelitian menunjukkan bahwa terdapat 2 aspek penelitian yang sudah memenuhi standar dan 3 aspek penelitian yang belum memenuhi standar. Kedua aspek yang telah memenuhi standar, berada pada tahap pendahuluan (antecendent). Ketiga aspek yang belum memenuhi standar terdapat pada tahap proses (transaction) dan tahap hasil (outcomes). 
Ketiga aspek yang belum memenuhi standar yaitu : (1) Pelaksanaan pembelajaran; (2) Pelaksanaan penilaian autentik; (3) Hasil penilaian autentik. Ketiga aspek dari dua tahapan yang belum memenuhi standar masih memerlukan rekomendasi atau pertimbangan didasarkan oleh ketimpangan-ketimpangan yang ditemui dalam penelitian. Apabila dibandingkan dengan penelitian terdahulu oleh Noviatmi (2015), hasil yang didapatkan berbeda. Berdasarkan penelitian Noviatmi pada tahap pendahuluan (antecedents) dan proses (transaction) masih memerlukan pertimbangan, sedangkan pada tahap hasil (outcomes) sudah 100\% memenuhi standar sehingga tidak diperlukan pertimbangan. Berdasarkan ketentuan dari Kemendikbud, keseluruhan aspek dalam Kurikulum 2013 harus $100 \%$ mencapai standar yang telah ditetapkan. Oleh karena itu, aspek-aspek yang belum memenuhi standar harus diberikan rekomendasi atau pertimbangan (judegement). Pertimbangan diberikan juga dengan memperhatikan hambatan-hambatan pada pelaksanaan implementasi Kurikulum 2013 yang ditemukan selama penelitian.

Aspek pertama pada tahap pendahuluan (antecedent) adalah kelengkapan perangkat Kurikulum 2013, khususnya pada pembelajaran matematika. Berdasarkan studi dokumentasi terhadap kelengkapan perangkat Kurikulum 2013 yang dimiliki oleh guru mata pelajaran matematika SMP Negeri 7 Salatiga, secara keseluruhan lengkap dan dalam kondisi yang sangat baik. Hasil penelitian menunjukkan kondisi kelengkapan perangkat Kurikulum 2013 pada mata pelajaran matematika di SMP Negeri 7 Salatiga 100\% memenuhi standar. Hal ini berarti tidak adanya ketimpangan antara kondisi yang ada dengan standar. Noviatmi (2015) dalam penelitiannya mengungkapkan bahwa dalam kelengkapan dokumen Kurikulum 2013 dan administrasi pembelajaran diperlukan adanya optimalisasi peran kepemimpinan dan supervisi kepala sekolah. Berdasarkan hal tersebut dapat dikatakan bahwa kepemimpinan dan supervisi kepala sekolah untuk SMP Negeri 7 Salatiga terkait dengan kelengkapan dokumen Kurikulum 2013 dan administrasi pembelajaran adalah sangat baik. Sejalan dengan kepemimpinan kepala sekolah yang sangat baik, guru mata pelajaran matematika di SMP Negeri 7 Salatiga juga telah menjalankan kewajibannya dalam kelengkapan Kurikulum 2013 dengan sangat baik. Adanya kelengkapan Kurikulum yang sesuai dengan standar akan membantu kelancaran proses belajar mengajar, termasuk dalam mendukung pembelajaran matematika yang aktif. Berdasarkan peraturan menteri pendidikan dan kebudayaan nasional Republik Indonesia terkait dengan perencanaan pembelajaran (2013), ada 9 indikator yang harus dipenuhi dalam pembuatan RPP. Kesembilan indikator itu terdiri dari : (1) Identitas mata pelajaran; (2) Pemilihan kompetensi; (3) Perumusan indikator; (4) Pemilihan materi pembelajaran; (5) Kegiatan pembelajaran; (6) Penilaian; (7) Pemilihan media belajar; (8) Pemilihan bahan pembelajaran (9) Pemilihan sumber pembelajaran. Secara keseluruhan Rencana Pelaksanaan Pembelajaran yang dibuat oleh guru mata pelajaran matematika adalah sudah memenuhi standar. Hal tersebut diketahui dari studi dokumentasi RPP yang dilakukan pada saat penelitian dengan hasil 100\% memenuhi standar. Wasino (2016) menemukan dan mendeskripsikan beberapa ketimpangan yang sangat terlihat dalam pembuatan RPP oleh guru mata pelajaran. Beberapa ketimpangan yang ditemukan tersebut yakni pada bagian : (1) pemilihan sumber belajar; (2) pemilihan media pembelajaran; (3) penilaian, sehingga penyusunan Rencana Pelaksanaan Pembelajaran (RPP) belum berjalan dengan maksimal. Ketimpangan-ketimpangan yang ditemukan dalam penelitian dapat membawa peneliti untuk menemukan hambatan-hambatan yang terjadi, baru kemudian dapat diberikan 
pertimbangan. Akan tetapi hasil penelitian menunjukkan bahwa RPP yang disusun oleh guru mata pelajaran matematika SMP Negeri 7 Salatiga sudah memenuhi standar penyusunan RPP Kurikulum 2013.

Dua aspek yang ditekankan dalam tahap proses atau transaction dalam penelitian ini, yakni pelaksanaan pembelajaran dan pelaksanaan penilaian autentik guru mata pelajaran matematika SMP Negeri 7 Salatiga. Peranan guru sebagai fasilitator sekaligus evaluator sangat menentukan jalannya kedua aspek yang sangat berkaitan ini. Terdapat tiga komponen penting dalam pelaksanaan pembelajaran yaitu kegiatan pendahuluan, kegiatan inti dan penutup pembelajaran. Tiga komponen tersebut sesuai dengan tiga komponen pelaksanaan pembelajaran berdasarkan Permendikbud nomor 22 tahun 2016 tentang standar proses. Sejalan dengan pendapat dan standar yang telah disebutkan, maka penelitian ini juga menggunakan tiga komponen tersebut sebagai komponen indikator dalam mengetahui keterlaksanaan pembelajaran matematika di SMP Negeri 7 Salatiga. Sesuai dengan hasil penelitian diketahui bahwa keterlaksanaan proses pembelajaran 60\% memenuhi standar. Masih terdapat $40 \%$ bagian yang belum sesuai dengan standar yang mana mengindikasikan adanya beberapa ketimpangan. Ketimpanganketimpangan tersebut dapat diketahui dengan menganalisis lebih lanjut hasil observasi pelaksanaan pembelajaran. Berdasarkan analisis lebih lanjut peneliti kemudian mendapatkan beberapa kesimpulan terkait pelaksanaan pembelajaran matematika Kurikulum 2013, yaitu : (1) pelaksanaan pembelajaran oleh guru belum maksimal; (2) masih terdapat kekurangan dalam pemberian apersepsi dan pengaitan materi dengan Iptek dan pengetahuan lain yang relevan; (3) guru belum maksimal dalam menerapkan pendekatan saintifik; (4) guru belum maksimal dalam penggunaan media pembelajaran; (5) manajemen waktu masih menjadi masalah dalam proses pembelajaran. Sehingga untuk aspek pelaksanaan pembelajaran masih memerlukan pertimbangan.

Evaluasi pelaksanaan penilaian autentik pada penelitian dilakukan dengan menggali informasi dari guru mata pelajaran matematika terkait dengan penilaian autentik melalui pengisian angket. Standar yang digunakan yaitu berdasarkan Permendikbud nomor 23 tahun 2016 tentang standar penilaian pendidikan (Mendikbud, 2016.b). Hasil penelitian menunjukkan bahwa untuk pelaksanaan penilaian autentik masih $40 \%$ dibawah standar. Persentase sebanyak $40 \%$ merupakan persentase yang besar, hampir dibawah setengah dari standar. Hal tersebut mengindikasikan adanya beberapa ketimpangan dalam pelaksanaan penilaian autentik sesuai dengan Kurikulum 2013 oleh guru mata pelajaran matematika. Berdasarkan angket yang diisi oleh guru mata pelajaran matematika dan analisis lebih lanjut oleh peneliti, semua guru menyatakan rutin dalam melakukan penilaian di akhir proses pembelajaran baik lisan maupun tulisan. Guru matematika juga melaksanakan penilaian autentik untuk mengukur ketiga aspek penilaian autentik, meskipun pelaksanaannya sendiri kurang maksimal. Pelaksanaan penilaian autentik dirasa cukup memberatkan guru karena karena banyaknya aspek yang harus dinilai dan banyaknya bentuk penilaian. Meskipun pada perencanaan pembelajaran sudah direncanakan, namun pada praktiknya jarang dilaksanakan. Menurut guru penilaian autentik dengan penilaian proyek dan portofolio masih sulit untuk diterapkan. Penyebabnya adalah guru merasa bahwa penilaian autentik dengan penilaian portofolio akan memberatkan siswa, khususnya bagi siswa dengan kondisi berkebutuhan khusus, sehingga hasilnya tetap akan kurang maksimal. Sebagai informasi, SMP Negeri 7 Salatiga juga merupakan sekolah yang menerapkan program 
sekolah inklusi, sehingga terdapat siswa yang berkebutuhan khusus. Oleh karena ketiga bentuk penilaian tersebut jarang dilakukan. Dapat dikatakan tugas yang diberikan kepada siswa memang kurang bervariasi. Temuan ini sejalan dengan hasil penelitian Wasino (2016) yang menemukan bahwa ketimpangan terbesar terdapat pada proses penilaian autentik. Berdasarkan hasil penelitian yang dilakukannya keterlaksanaan penilaian autentik menghasilkan skor 2,59 dari skor standar yaitu 4. Menurut para stakeholder pendidikan masalah penilaian memang masih menjadi suatu isu dalam pelaksanaan Kurikulum 2013. Berdasarkan pemaparan tentang pelaksanaan penilaian autentik, dapat dikatakan bahwa aspek ini masih menjadi isu dalam implementasi Kurikulum 2013.

Tahapan terakhir dari penelitian ini adalah tahap hasil atau outcomes. Hasil penilaian autentik siswa SMP Negeri 7 Salatiga merupakan fokus penelitian dari tahap hasil (outcomes) dalam penelitian ini. Berdasarkan hasil penelitian untuk hasil penilaian autentik masih sangat memerlukan rekomendasi atau pertimbangan karena kategori kurang dan sangat kurang ditemukan sangat besar atau jauh dari memenuhi standar, yaitu sebesar 83,3\%. Sesuai dengan Kurikulum 2013 terdapat tiga aspek yang dinilai, yakni pengetahuan, sikap dan keterampilan. Pemerintah melalui Kemendikbud tentunya telah mengatur kriteria untuk evaluasi atau penilaian autentik, yaitu yang disebut dengan Kriteria Ketuntasan Minimal (KKM). Berdasarkan hasil penelitian diketahui bahwa untuk aspek pengetahuan (matematika) yang memenuhi kriteria ketuntasan minimal hanya ada 6 kelas dari jumlah keseluruhan kelas yakni 24 kelas. Kemudian juga diketahui bahwa untuk aspek keterampilan terdapat 12 kelas dari jumlah 24 kelas yang sudah mencapai kriteria ketuntasan minimal (minimal B-) di SMP Negeri 7 Salatiga. Selanjutnya diketahui bahwa untuk aspek sikap sudah $100 \%$ dari keseluruhan kelas yang memenuhi memenuhi standar, yakni 24 kelas. Berdasarkan analisis terkait hasil penilaian autentik peneliti menemukan beberapa kesimpulan, yaitu : (1) hasil penilaian autentik siswa masih terbilang rendah; (2) melalui penilaian pada aspek pengetahuan dan keterampilan diketahui bahwa daya serap dan motivasi siswa dalam pembelajaran matematika masih terbilang rendah; (3) hasil penilaian autentik juga dipengaruhi oleh program inklusi yang diterapkan oleh sekolah; (4) keterampilan berfikir siswa masih terbilang rendah sehingga menjadi tantangan bagi guru matematika untuk dapat meningkatkan daya berpikir kritis siswa (5) pada aspek sikap, diketahui bahwa keseluruhan kelas sudah memenuhi standar dan patut untuk dijadikan teladan.

Adapun pertimbangan-pertimbangan yang dapat diberikan didasarkan dari hasil penelitian yang dibandingkan dengan standar, teori-teori, pendapat peneliti dan masukan dari guru pendamping. Dalam penelitian ini pertimbangan diberikan khususnya terkait dengan ketiga aspek penelitian yang diketahui masih belum memenuhi standar. Ketiga aspek tersebut adalah aspek pelaksanaan pembelajaran, aspek penilaian autentik, dan aspek hasil penilaian autentik. Sasaran pertimbangan atau rekomendasi adalah guru, kepala sekolah, orang tua, serta bagi stakeholder pendidikan. Harapannya adalah pertimbangan dapat memberikan manfaat bagi guru, kepala sekolah, orang tua, stakeholder pendidikan, dan terutama bagi siswa.

\section{SIMPULAN DAN SARAN \\ Simpulan}

Berdasarkan hasil penelitian dapat ditarik beberapa kesimpulan. Hasil penelitian pada tahap pendahuluan (antecedents) pada aspek kelengkapan Kurikulum dan perencanaan pembelajaran tidak memerlukan judgement atau pertimbangan. Sebaliknya, hal ini dapat menjadi contoh bagi sekolah 
pelaksana Kurikulum 2013 lainnya yang masih mengalami kendala dalam menginventarisir kelengkapan Kurikulum 2013. Pada tahap proses atau transaction dalam penelitian ini, yakni pelaksanaan pembelajaran dan pelaksanaan penilaian autentik oleh guru mata pelajaran matematika SMP Negeri 7 Salatiga, disimpulkan bahwa kedua aspek masih memerlukan pertimbangan karena belum memenuhi standar. Hasil penelitian pada tahap outcomes yaitu terkait hasil penilaian autentik siswa, dapat disimpulkan bahwa aspek ini masih sangat memerlukan rekomendasi karena ketimpangan terbesar ditemukan dalam aspek ini.

\section{Saran}

Berdasarkan pembahasan dan simpulan hasil penelitian, maka dapat diberikan beberapa saran atau rekomendasi (pertimbangan) terkait implementasi Kurikulum 2013 pada mata pelajaran matematika. Wajib bagi seorang guru untuk mencari lebih banyak referensi untuk memotivasi siswa dalam proses pembelajaran matematika. Guru juga wajib memperhatikan tahapan dalam penerapan pendekatan saintifik, karena pendekatan saintifik merupakan karakteristik Kurikulum 2013. Apabila dengan tambahan kesiapan guru sebelum masuk ke kelas dan dengan strategi pembelajaran yang tepat untuk materi yang akan dibawakan, maka guru matematika tidak akan menemui hambatan dalam memanajemen waktu sehingga pembelajaran akan lebih berkualitas. Terkait penilaian autentik Kurikulum 2013 yang dilaksanakan oleh guru perlu mendapat perhatian lebih dari pemerintah, khususnya dinas pendidikan dan kebudayaan. Pelatihan yang diberikan kepada guru harus lebih intens lagi. Supervisi kepala sekolah terkait pelaksanaan penilaian autentik juga akan sangat membantu guru dalam meningkatkan kualitas kerjanya. Orang tua juga wajib memberikan dukungan moril, agar anak termotivasi untuk berprestasi. Apabila guru, kepala sekolah dan orang tua dapat saling bekerja sama, maka akan dapat meningkatkan motivasi siswa, sehingga daya serap dan kemampuan berpikir kritis siswa juga dapat meningkat, dan otomatis meningkatkan hasil penilaian autentik siswa. Peneliti berharap agar penelitian ini dapat bermanfaat bagi guru, kepala sekolah, orang tua dan terutama siswa.

\section{DAFTAR PUSTAKA}

Beckmann, R.G., Clarke, B., Foegen, A., Marsh, L., Star, J. R., \& Witzel, B. (2009). Assisting Students Struggling with Mathematics: Response to Intervention (RtI) for Elementary and Middle Schools. NCEE 20094060. What Works Clearinghouse

Direktorat Pembinaan, S. D., \& Dasar, D. J. P. (2013). Kemendikbud. 2013. Buku Panduan Penguatan Proses Pembelajaran Kurikulum.

Mardapi, D. (2008). Teknik Penyusunan Instrumen Tes dan Nontes. Yogyakarta: Mitra Cendekia.

Mendikbud. (2016.a). Peraturan Menteri Pendidikan dan Kebudayan RI No.22 tahun 2016 tentang Standar Proses Pendidikan Dasar dan Menengah. Jakarta: Departemen Pendidikan dan Kebudayaan

Mendikbud. (2016.b). Peraturan Menteri Pendidikan dan Kebudayan RI No.23 tahun 2016 tentang Standar Penilaian Pendidikan Dasar dan Menengah. Jakarta: Departemen Pendidikan dan Kebudayaan

Noviatmi, A. (2015). Evaluasi Implementasi Kurikulum 2013 Kelas I \& IV SD Di Kabupaten Magelang Tahun Pelajaran 2014/2015 (Doctoral dissertation, UNY).

Nurmin, N., \& Kartowagiran, B. (2013). Evaluasi Kemampuan Guru dalam Mengimplementasi Pembelajaran 
Tematik di SD Kecamatan Salahutu Kabupaten Maluku Tengah. Jurnal Prima Edukasia, 1(2), 184-194.

Republik Indonesia. (2033).Undang-Undang, R. I. No. 20 Tahun 2003 tentang Sistem Pendidikan Nasional. 2003. Jakarta: Sinar Grafika.

Wasino. (2016). Evaluasi Kurikulum 2013 Dikalangan Guru SMP di Cluster 2 Kabupaten Boyolali Tahun 2015:
Analisis RPP dan Pelaksanaan Pembelajaran (Tesis, Magister Manajemen Pendidikan Program Pascasarjana FKIP-UKSW).

Widoyoko, E. P. (2009). Evaluasi program pembelajaran. Yogyakarta: Pustaka Pelajar.

Yusuf, F. (2000). Evaluasi Program. Jakarta: PT Rineka Cipta. 